\title{
PENGARUH MOTIVASI KERJA DAN DISIPLIN KERJA TERHADAP KEPUASAN KERJA
}

\section{(Studi Pada Salah Satu Instansi Pemerintah di Kabupaten Bandung)}

\author{
Ruddy Heryadi ${ }^{1}$, Soelaiman Sukmalana ${ }^{2}$ \\ Dinas Perhubungan Kabupaten Bandung ${ }^{1}$ \\ STIE Pasundan, Bandung ${ }^{2}$ \\ Email: ruddyheryadi@gmail.com ${ }^{1}$,sukmalana@stiepas.ac.id ${ }^{2}$
}

\begin{abstract}
This research departs from phenomena that indicate inadequate job satisfaction caused by low work motivation and employee discipline. For this reason, the research aims to analyze the effect of work motivation and work discipline on job satisfaction. Quantitative research method approach using employee respondents who work in one of the government agencies in Bandung Regency as many as 120 employees. The sample frame uses the rank and work class of employees. The data analysis technique uses path analysis with results showing an influence of work motivation and work discipline on employee job satisfaction. The actual influence is $58.2 \%$, while the rest influence by other factors not examined in this study.
\end{abstract}

Keywords: work motivation, work discipline, employee job satisfaction.

\begin{abstract}
Abstrak
Penelitian ini berangkat dari adanya fenomena di lapangan yang mengindikasikan adanya kepuasan kerja yang belum memadai yang diduga disebabkan oleh rendahnya motivasi kerja dan disiplin kerja pegawai. Untuk itu penelitian bertujuan untuk menganalisis pengaruh motivasi kerja dan disiplin kerja terhadap kepuasan kerja. Metode penelitian kuantitatif dengan menggunakan responden pegawai yang bekerja pada salah satu instansi pemerintah di Kabupaten Bandung sebanyak 120 orang pegawai. Sample frame menggunakan pangkat dan golongan kerja pegawai. Teknik analisis data menggunakan analisis jalur dengan hasil yang
\end{abstract}


menunjukkan terdapat pengaruh motivasi kerja dan disiplin kerja terhadap kepuasan kerja pegawai. Total pengaruh secara keseluruhan sebesar 58,2\% sedangkan sisanya dipengaruhi oleh factor lain yang tidak diteliti pada penelitian ini.

\section{Kata kunci: motivasi kerja, disiplin kerja, kepuasan kerja pegawai.}

\section{PENDAHULUAN}

Dalam rangka mewujudkan tujuan pembangunan nasional maka perlu ditunjang oleh tenaga kerja yang mempunyai kompetensi yang merupakan tenaga kerja mempunyai pengetahuan, keahlian, kepiawaian dan perilaku yang diperlukan untuk melaksanakan tugas atau pekerjaan guna mencapai kinerja maksimal yang menjadi tujuan lembaga/organisasi tersebut. Untuk mencapai hal tersebut tidak terlepas dari perilaku individu tersebut dalam organisasi, perilaku individu di dalam organisasi didukung oleh suasana kerja yang kondusif dan hal lainnya yang memberikan dorongan kuat dalam menyelesaikan tugas yang diembannya. Dorongan yang kuat tersebut dapat menyebabkan kepuasan kerja individu yang merupakan salah satu factor yang dapat memacu kinerja individu.

Untuk mencapai tujuan instansi maka perlu dioptimalkannya semua sumber daya yang ada di instansi tersebut. Dalam manajemen fungsi manajemen sumber daya manusia merupakan salah satu factor yang mendorong dalam meningkatkan kinerja organisasi. Faktor yang dominan berpengaruh terhadap kinerja pegawai yaitu kepusaan kerja. Penelitian yang dilakukan oleh Hersona \& Sidharta (2017) menyatakan bahwa implikasi manajerial yang signifikan antara disiplin kerja terhadap kinerja pegawai. Lebih lanjut De Sousa Sabbagha, Ledimo \& Martins (2018) meprediksi akan adanya pengaruh positif motivasi kerja terhadap kepuasan kerja. Penelitian yang dilakukan oleh Raza, Akhtar, Husnain \& Akhtar (2015) menunjukkan terdapat pengaruh motivasi kerja terhadap kepuasan kerja. Hal ini menunjukan bahwa kepuasan kerja berkaitan erat dengan pencapaian tujuan yang telah ditetapkan oleh organisasi melalui peningkatan motivasi kerja dan disiplin pegawai.

Kinerja pegawai merupakan hasil secara kualitas dan kuantitas yang dicapai oleh seorang pegawai dalam melaksanakan tugasnya sesuai dengan tanggung jawab yang diberikan kepadanya dan kinerja pegawai salah satunya dipengaruhi oleh faktor kepuasan kerja.

Untuk meningkatkan kinerja, selain harus ditunjang oleh kepuasan pegawainya, diperlukan suatu motivasi bagi pegawai, karena pada dasarnya para pegawai mempunyai kebutuhan dan harapan yang berbeda. Disamping itu sebagai manusia 
mereka tidak terlepas dari berbagai macam keinginan maupun kebutuhan yang mendorong untuk mencapai tujuannya. Kebutuhan ini dapat dipandang sebagai pembangkit, penguat atau penggerak perilaku seseorang, dimana apabila masih terdapat kekurangan akan kebutuhannya maka orang tersebut akan merasa termotivasi untuk tercapainya pemenuhan kebutuhan tersebut.

Menumbuhkan motivasi pegawai untuk mau bekerja dalam pencapaian tujuan dan sasaran instansi secara spesifik dan efisien bisa berbeda karena perilaku tiap individu juga berbeda. Ada beberapa faktor khusus yang menyebabkan perbedaan individu dalam perilaku diantaranya adalah: persepsi, sikap dan kepribadian setiap individu. Motif berprestasi merupakan suatu dorongan dalam diri pegawai untuk melakukan suatu kegiatan atau tugas dengan sebaik-baiknya agar mampu mencapai kinerja yang optimal. (Avery, Smillie \& Fife-Schaw, 2015).

Data dilapangan menunjukkan bahwa selain motivasi pegawai yang belum optimal juga disebabkan oleh rendahnya kedisiplinan pegawai. Disiplin pegawai merupakan kesanggupan pegawai untuk mentaati kewajiban dan menghindari larangan yang ditentukan dalam peraturan perundang-undangan dan/ atau peraturan kedinasan yang apabila tidak ditaati atau dilanggar dijatuhi hukuman disiplin. Latar belakang permasalah menunjukkan permasalahan dimana motivasi kerja, disiplin kerja, dan kepuasan kerja pegawai masih belum memadai oleh karena itu tujuan penelitian ini adalah untuk mengetahui dan mengkaji motivasi kerja dan disiplin kerja pegawai terhadap kepuasan kerja pada salah satu instansi pemerintah di Kabupaten Bandung.

\section{KERANGKA PEMIKIRAN}

Hersona \& Sidharta (2017) mengindikasikan bahwa disiplin yang baik mencerminkan besarnya tanggungjawab seseorang terhadap tugas-tugas yang diberikan kepadanya. Terdapat beberapa aspek yang dapat mempengaruhi kinerja organisasi atau individu yaitu seperti motivasi (Islami, Mulolli \& Mustafa, 2018), komitmen (Nath Gangai \& Agrawal, 2015), kompetensi (Trivellas, Kakkos, Blanas \& Santouridis, 2015), perilaku (Sidharta, 2018), kemangkiran dan kepuasan kerja (Dyrbye, Shanafelt, Johnson, Johnson, Satele \& West, 2019). Hal ini mengisyaratkan bahwa faktor penentu dalam meningkatkan efektivitas organisasi sangat di pengaruhi oleh sumber daya manusianya. Hal ini mendorong gairah kerja, semangat kerja, dan terwujudnya tujuan perusahaan, karyawan, serta masyarakat pada umumnya.

Berdasarkan hasil penelitian Manik \& Sidharta (2017) menyimpulkan bahwa ada hubungan yang positif antara motivasi berprestasi dengan pencapaian kinerja. 
Seseorang yang mempunyai motivasi berprestasi tinggi akan mencapai kinerja tinggi, dan sebaliknya mereka yang kinerjanya rendah disebabkan mitivasi kerjanya rendah. Pemenuhan kebutuhan pegawai merupakan fundamen yang mendasari perilaku kerja. Tidak mungkin dapat memotivasi pegawai tanpa memperhatikan apa yang dibutuhkan.

Tingginya kepuasan kerja merupakan tanda dari organisasi yang dikelola dengan baik. Kepuasan kerja yang rendah sering menjadi penyebab unjuk rasa yang liar, penurunan kerja, ketidak hadiran, dan keluar masuk karyawan yang tinggi. Dyrbye, Shanafelt, Johnson, Johnson, Satele \& West (2019) menyatakan bahwa disiplin kerja dapat diartkan sebagai pelaksanaan manajemen untuk memperteguh pedoman organisasional. ini mengisyaratkan bahwa untuk memberikan kepuasan kerja akan bergantung dari penerapan disiplin kerja untuk memperteguh pedoman organisasi sesuai dengan tujuannya sehingga efektivitas organisasi dapat berjalan dengan baik. Hal ini bisa mengakibatkan keluhan, rendahnya kinerja, kualitas produk rendah, pencurian dan sabotase oleh karyawan, masalah disiplin, dan berbagai masalah organisasi yang lain.

Motivasi sebagai suatu kondisi yang menggerakkan manusia pada suatu tujuan tertentu (Manik \& Sidharta, 2017). Motivasi yang ada pada seseorang akan mewujudkan suatu perilaku yang diarahkan pada tujuan mencapai sasaran kepuasan. Tiap kegiatan yang dilakukan oleh seseorang didorong oleh sesuatu kekuatan dari dalam diri orang tersebut, kekuatan pendorong inilah yang disebut motivasi. Motivasi adalah masalah komplek dalam organisasi, karena kebutuhan, keinginan setiap organisasi berbeda. Tinggi rendahnya motivasi karyawan didalam suatu organisasi berdampak pada kepuasan kerja karyawan. Kepuasan kerja dapat mempengaruhi kehadiran seseorang dalam dunia kerja, yang selanjutnya juga berpengaruh terhadap kemauan untuk bekerja. Keinginan pegawai atau motivasi untuk bekerja biasanya ditujukan dengan dukungan aktivitas yang mengarah pada tujuan.

Disiplin kerja tidak semata-mata patuh dan taat terhadap penggunaan jam kerja saja misalnya datang dan pulang sesuai jadwal, tidak mangkir jika bekerja, dan tidak mencuri-curi waktu. Upaya dalam mentaati peraturan tidak didasarkan adanya perasaan takutatau terpaksa. Komitmen dan loyal pada organisasi yaitu tercermin dari berbagai sikap dalam bekerja, misalnya tidak pernah mengeluh, tidak berpura-pura sakit, tidak manja, dan bekerja dengan semangat tinggi. (Ziaud-Din, Arif \& Shabbir, 2017)

Cantarelli, Belardinelli \& Belle (2016) melakukan penelitian meta analisis menyebutkan bahwa kepuasan atau ketidakpuasan adalah sebuah kondisi akhir yang timbul karena dicapainya tujuan tertentu hal tersebut berupa reaksi efektif sang karyawan. Berdasarkan pernyataan tersebut dapat dikatakan bahwa kepuasan 
kerja menunjukkan kesesuaian antara harapan seseorang akan sesuatu dengan apa yang benar-benar diterimanya, sehingga dapat dikatakan bahwa kepuasan kerja berbeda untuk setiap individu. Hal ini disebabkan karena masing-masing individu memiliki perbedaan dalam nilai-nilai yang dianutnya, sikap, perilaku-perilaku maupun motivasi untuk bekerja.

\section{METODE PENELITIAN}

Penelitian ini menggunakan penelitian deskriptif merupakan penelitian terhadap masalah-masalah berupa fakta-fakta saat ini dari suatu populasi. Tujuan penelitian deskriptif adalah untuk menguji hipotesis atau menjawab pertanyaan yang berkaitan dengan current status dari subjek yang diteliti. Penelitian ini dilaksanakan pada salah satu instansi pemerintahan di Kabupaten Bandung selama 6 bulan

Untuk menentukan banyaknya sampel pada penelitian ini menggunakan metode Slovin diperoleh ukuran sampel sebesar 120 orang dengan sample frame golongan dan jabatan sebagai acuan untuk menetukan proporsional responden.

Operasionalisasi variabel dalam penelitian ini yaitu adalah Motivasi kerja (X1), disiplin kerja (X2) Kepuasan Kerja (Y). Motivasi kerja dikembangkan dari teori McClleland sedangkan disiplin kerja mengadopsi instrumen yang digunakan oleh Hersona \& Sidharta (201) sedangkan kepuasan kerja menggunakan Job Description Indeks (JDI) yang dikembangkan oleh Smith, Kendall \& Hulin (1969).

Uji validitas digunakan untuk mengetahui sejauh mana keakuratan dan ketelitian antara hasil pengukuran dari variable yang diteliti dibandingkan dengan teori yang ada. Hasil penelitian dikatakan valid apabila terdapat kesamaan antara data yang terkumpul dengan data yang sesungguhnya terjadi pada objek yang diteliti. Sedangkan pengujian reliabilitas instrument dalam penelitian ini akan dilakukan secara internal. Teknik analisis inferensial digunakan yaitu teknik analisis jalur.

\section{HASIL DAN PEMBAHASAN}

\section{Responden}

Karakteristik responden berdasarkan jenis kelamin menunjukan bahwa dilihat darijenis kelamin, jumlah responden pria sebesar 97,5\%, sedangkan responden wanita sebesar 2,5\%. Dengan demikian jumlah responden wanita lebih banyak dari responden pria. Karakteristik responden berdasarkan usia menunjukan bahwa 
mayoritas responden, yang berusia lebih dari 20-30 Th, yaitu sebanyak 54 atau 45 $\%$, kedua yang berusia di atas $31 \mathrm{~s} / \mathrm{d} 40$ tahun, yaitu sebanyak 30 atau sebesar 25 $\%$, sedangkan yang ketiga responden yang berusia 41 s/d $50 \mathrm{Th}$, yaitu sebanyak 18 atau $15 \%$, dan yang terkecil responden yang berusia $>50 \mathrm{Th}$, yaitu sebanyak 1 atau $0,83 \%$.

Tabel 1. Hasil Uji Validitas Instrumen Variabel Motivasi Kerja

\begin{tabular}{|c|c|c|}
\hline Item & Skor & Kategori \\
\hline X1.1 & 0.535 & Valid \\
\hline $\mathrm{X} 1.2$ & 0.444 & Valid \\
\hline X1.3 & 0.517 & Valid \\
\hline X1.4 & 0.563 & Valid \\
\hline $\mathrm{X} 1.5$ & 0.599 & Valid \\
\hline X1.6 & 0.491 & Valid \\
\hline X1.7 & 0.586 & Valid \\
\hline X1.8 & 0.403 & Valid \\
\hline X1.9 & 0.554 & Valid \\
\hline $\mathrm{X} 1.10$ & 0.465 & Valid \\
\hline $\mathrm{X} 1.11$ & 0.398 & Valid \\
\hline $\mathrm{X} 1.12$ & 0.315 & Valid \\
\hline $\mathrm{X} 1.13$ & 0.324 & Valid \\
\hline $\mathrm{X} 1.14$ & 0.571 & Valid \\
\hline X1.15 & 0.558 & Valid \\
\hline
\end{tabular}

Sumber: Data Primer diolah kembali

Pernyataan dalam instrumen variabel motivasi kerja di atas terdiri dari 15 item.

Hasil uji variabel tersebut memenuhi kriteria yang disyaratkan yaitu >0,30.

Dengan demikian dapat disimpulkan bahwa butir pernyataan 1 sampai 15 dapat dinyatakan valid dan benar-benar sebagai indikator varibael motivasi kerja. 
Heryadi, Pengaruh Motivasi Kerja dan Disiplin Kerja

October , 2020

Tabel 2. Hasil Uji Validitas Instrumen Variabel Disiplin Kerja

\begin{tabular}{|c|c|c|}
\hline Item & Skor & Kategori \\
\hline X2.1 & 0.340 & Valid \\
\hline X2.2 & 0.450 & Valid \\
\hline X2.3 & 0.413 & Valid \\
\hline X2.4 & 0.557 & Valid \\
\hline X2.6 & 0.477 & Valid \\
\hline X2.7 & 0.394 & Valid \\
\hline X2.8 & 0.496 & Valid \\
\hline X2.9 & 0.417 & Valid \\
\hline X2.10 & 0.482 & Valid \\
\hline X2.11 & 0.378 & Valid \\
\hline X2.13 & 0.384 & Valid \\
\hline X2.14 & 0.456 & Valid \\
\hline X2.15 & 0.371 & Valid \\
\hline
\end{tabular}

Sumber: Data primer diolah kembali

Pernyataan dalam instrumen variabel disiplin kerja di atas terdiri dari 15 item.

Hasil uji variabel tersebut memenuhi kriteria yang disyaratkan yaitu >0,30.

Dengan demikian dapat disimpulkan bahwa butir pernyataan 1 sampai 15 dapat dinyatakan valid dan benar-benar sebagai indikator variabel disiplin kerja.

Tabel 3. Hasil Uji Validitas Instrumen Variabel Kepuasan Kerja

\begin{tabular}{|c|c|c|}
\hline Item & Skor & Kategori \\
\hline Y.1 & 0.564 & Valid \\
\hline Y.2 & 0.435 & Valid \\
\hline Y.3 & 0.394 & Valid \\
\hline Y.4 & 0.336 & Valid \\
\hline Y.5 & 0.598 & Valid \\
\hline Y.6 & 0.591 & Valid \\
\hline Y.7 & 0.345 & Valid \\
\hline Y.8 & 0.390 & Valid \\
\hline Y.9 & 0.464 & Valid \\
\hline Y.10 & 0.347 & Valid \\
\hline Y.11 & 0.579 & Valid \\
\hline Y.12 & 0.483 & Valid \\
\hline Y.13 & 0.335 & Valid \\
\hline Y.14 & 0.354 & Valid \\
\hline Y.15 & 0.401 & Valid \\
\hline
\end{tabular}

Sumber: Data primer diolah kembali 
October , 2020

Pernyataan dalam instrumen variabel kepuasan kerja di atas terdiri dari 15 item.

Hasil uji variabel tersebut memenuhi kriteria yang disyaratkan yaitu > 0,30.

Dengan demikian dapat disimpulkan bahwa butir pernyataan 1 sampai 15 dapat dinyatakan valid dan benar-benar sebagai indikator variabel kepuasan kerja.

Tabel 4. Rekapitulasi Hasil Uji Reliabilitas

\begin{tabular}{|c|l|c|c|}
\hline No. & \multicolumn{1}{|c|}{ Variabel } & Skor & Kategori \\
\hline 1. & Motivasi Kerja (X1) & 0.849 & Reliabel \\
\hline 2. & Disiplin Kerja (X2) & 0.806 & Reliabel \\
\hline 3. & Kepuasan Kerja (Y) & 0.825 & Reliabel \\
\hline
\end{tabular}

Sumber: Data Primer diolah kembali

Hasil uji reliabilitas di atas dapat dinyatakan bahwa semua variabel termasuk kategori reliabel, karena skornya $>0,70$. Dengan demikian instrumen penelitian yang digunakan masing-masing variabel pada penelitian ini dapat dinyatakan reliabel dan benar-benar sebagai alat ukur yang handal dan memiliki tingkat kestabilan yang tinggi, dalam arti alat ukur tersebut apabila dilakukan secara berulang, hasil dari pengujian instrumen tersebut akan menunjukkan hasil yang tetap.

Berdasarkan hasil perhitungan dapat diketahui hasil analisis jalur seperti yang dijelaskan pada gambar 1 dibawah ini.

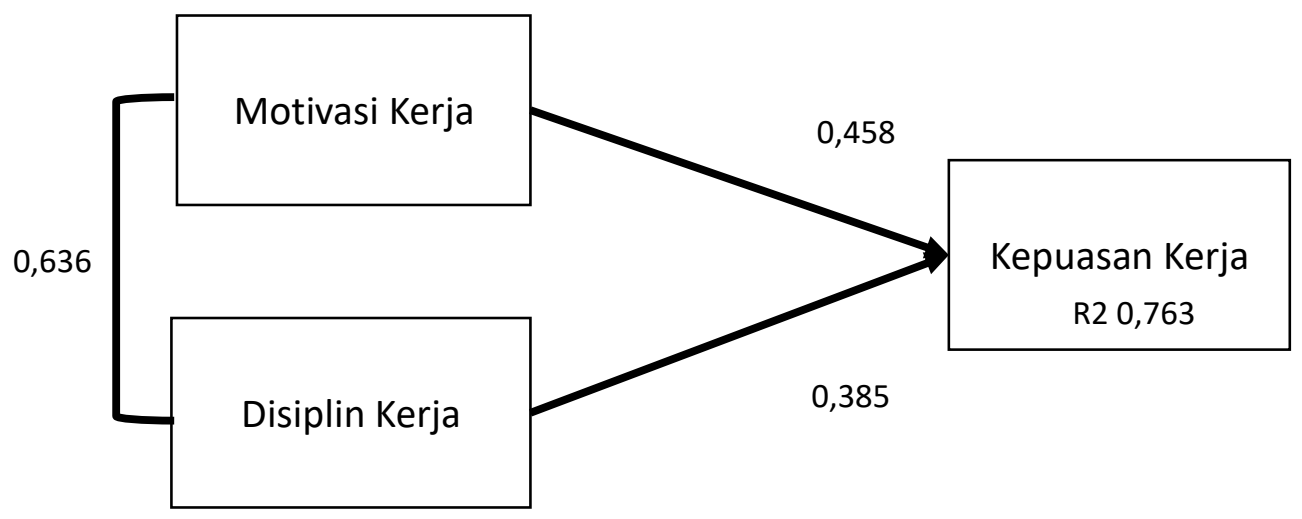

Gambar 1. Hasil analisis Jalur

Bisnis Dan Iptek | Sekolah Tinggi Ilmu Ekonomi Pasundan Bandung 
Hasil perhitungan jalur, bahwa variabel X1 mempunyai koefisien jalur sebesar 0,456, Variabel X2 mempunyai koefisien jalur sebesar 0,385. Berdasarkan gambar tersebut di atas, maka diperoleh persamaan jalur sebagai berikut;

$\mathrm{Y}=0,456 \mathrm{X} 1+0,385 \mathrm{X} 2+\mathrm{C} 1$

Besarnya pengaruh antar variable penelitian terlihat bahwa variabel Motivasi Kerja (X1) mempunyai pengaruh langsung sebesar 20,98 \%, pengaruh tidak langsung melalui hubungannya dengan Disiplin Kerja (X2) sebesar 11,21 \%, dan total pengaruhnya adalah sebesar $32,19 \%$.

Variabel Disiplin Kerja (X2) mempunyai pengaruh langsung sebesar 14,82 \%, pengaruh tidak langsung melalui hubungannya dengan Motivasi Kerja (X1) sebesar $11,21 \%$, dan total pengaruhnya sebesar $26,04 \%$.

Hasil perhitungan Koefisien determinasi ( $\mathrm{R}$ kuadrat) yang dinyatakan dalam persentase mengambarkan besarnya kontribusi semua variabel bebas yaitu Motivasi Kerja (X1) dan Disiplin Kerja (X2), dalam menentukan variasi Kepuasan Kerja (Y) adalah sebesar 58,23 \%. Sedangkan faktor lain yang tidak diteliti dan turut mempengaruhi Kepuasan Kerja ditunjukan oleh nilai Pye = 0,4177 atau sebesar $41,77 \%$.

Sesuai dengan hasil pengolahan data yang dilakukan, diperoleh hasil pengaruh Motivasi Kerja (X1) terhadap Kepuasan Kerja (Y) sebesar 32,19 \%. Hasil penelitian ini mendukung penelitian yang dilakukan oleh Cantarelli, Belardinelli \& Belle (2016) yang membuktikan terdapat pengaruh signifikan motivasi kerja terhadap kepuasan kerja pegawai.

Hal tersebut menunjukan bahwa terdapat pengaruh Motivasi Kerja (X1) terhadap Kepuasan Kerja (Y). Berdasarkan hasil penelitian Avery, Smillie \& Fife-Schaw (2015) menyimpulkan bahwa ada hubungan yang positif antara motivasi berprestasi dengan pencapaian kinerja. Seseorang yang mempunyai motivasi berprestasi tinggi akan mencapai kepuasan kerja tinggi, dan sebaliknya mereka yang kepuasan kerjanya rendah disebabkan motivasi kerjanya rendah.

Pemenuhan kebutuhan pegawai merupakan hal dasar yang mendasari perilaku kerja. Tidak mungkin dapat memotivasi pegawai tanpa memperhatikan apa yang dibutuhkan. Motivasi Kerja merupakan kontribusi terbesar dalam meningkatkan kepuasan kerja pegawai. Untuk itu peran dari pemimpin dalam meningkatkan Motivasi Kerja perlu dilakukan sehingga kepuasan pegawai dapat dicapai dengan optimal.

Sesuai dengan hasil pengolahan data yang dilakukan, diperoleh hasil pengaruh Disiplin Kerja (X2) terhadap Kepuasan Kerja (Y) sebagai berikut: Variabel 
Disiplin Kerja (X2) mempunyai pengaruh langsung sebesar 2,1\%, pengaruh tidak langsung melalui hubungannya dengan Motivasi Kerja (X1) sebesar 5,7\%, dan pengaruh tidak langsung melalui Variabel Kepuasan Kerja (X3) sebesar 3\%, sehingga total pengaruhnya sebesar 10,8\%. Hasil penelitian ini mendukung penelitian yang dilakukan oleh Sofyan, Rahman, Bima \& Nujum (2016) yang membuktikan terdapat pengaruh signifikan Disiplin Kerja terhadap Kepuasan kerja pegawai.

Hal tersebut menunjukan bahwa terdapat pengaruh Disiplin Kerja (X2) terhadap Kepuasan Kerja (Y). Ini sesuai dengan Hersona \& Sidharta (2017) bahwa disiplin kerja dapat diartkan sebagai pelaksanaan manajemen untuk memperteguh pedoman organisasional. ini mengisyaratkan bahwa untuk memberikan kepuasan kerja akan bergantung dari penerapan disiplin kerja untuk memperteguh pedoman organisasi sesuai dengan tujuannya sehingga efektivitas organisasi dapat berjalan dengan baik. Hal ini bisa mengakibatkan keluhan, rendahnya kinerja, kualitas produk rendah, pencurian dan sabotase oleh karyawan, masalah disiplin, dan berbagai masalah organisasi yang lain (Dyrbye, Shanafelt, Johnson, Johnson, Satele \& West, 2019).

Sesuai dengan hasil pengolahan data yang dilakukan, diperoleh hasil pengaruh Motivasi Kerja (X1) dan Disiplin Kerja (X2) terhadap Kepuasan Kerja (Y) sebesar 58,24\%. Sedangkan sisanya sebesar $41,77 \%$ disebabkan oleh pengaruh variabel lain seperti komitmen, kompetensi, etos kerja, dan sebagainya yang tidak termasuk dalam penelitian ini. Hal ini menunjukan bahwa kedua variabel tersebut di atas Motivasi Kerja (X1) dan Disiplin Kerja (X2) secara bersama-sama dan bersinergi dengan baik memiliki pengaruh yang signifikan terhadap Kepuasan $\operatorname{Kerja}(Y)$.

Hal ini mengindikasikan bahwa baiknya motivasi kejrja dan disiplin pegawai akan seiring dengan peningkatan kepuasan pegawai. Dengan demikian, perlu adanya upaya mempertahankan nilai-nilai Kepuasan Kerja yang sudah berjalan dan bahkan sedapat mungkin ditingkatkan. Motivasi yang ada pada seseorang akan mewujudkan suatu perilaku yang diarahkan pada tujuan mencapai sasaran kepuasan. Tiap kegiatan yang dilakukan oleh seseorang didorong oleh sesuatu kekuatan dari dalam diri orang tersebut, kekuatan pendorong inilah yang disebut motivasi. Motivasi adalah masalah komplek dalam organisasi, karena kebutuhan, keinginan setiap organisasi berbeda. Tinggi rendahnya motivasi karyawan didalam suatu organisasi berdampak pada kepuasan kerja karyawan. Kepuasan kerja dapat mempengaruhi kehadiran seseorang dalam dunia kerja, yang selanjutnya juga berpengaruh terhadap kemauan untuk bekerja. Keinginan pegawai atau motivasi untuk bekerja biasanya ditujukan dengan dukungan aktivitas yang mengarah pada tujuan. 
Disiplin kerja tidak semata-mata patuh dan taat terhadap penggunaan jam kerja saja misalnya datang dan pulang sesuai jadwal, tidak mangkir jika bekerja, dan tidak mencuri-curi waktu. Upaya dalam mentaati peraturan tidak didasarkan adanya perasaan takutatau terpaksa. Komitmen dan loyal pada organisasi yaitu tercermin dari berbagai sikap dalam bekerja, misalnya tidak pernah mengeluh, tidak berpura-pura sakit, tidak manja, dan bekerja dengan semangat tinggi.

Cantarelli, Belardinelli \& Belle (2016) menyebutkan bahwa kepuasan atau ketidakpuasan adalah sebuah kondisi akhir yang timbul karena dicapainya tujuan tertentu hal tersebut berupa reaksi efektif sang karyawan. Berdasarkan pernyataan tersebut dapat dikatakan bahwa kepuasan kerja menunjukkan kesesuaian antara harapan seseorang akan sesuatu dengan apa yang benar-benar diterimanya, sehingga dapat dikatakan bahwa kepuasan kerja berbeda untuk setiap individu. Hal ini disebabkan karena masing-masing individu memiliki perbedaan dalam nilai-nilai yang dianutnya, sikap, perilaku-perilaku maupun motivasi untuk bekerja.

\section{KESIMPULAN}

Gambaran motivasi kerja berada dalam kategori cukup baik. Meskipun begitu terdapat aspek yang belum memadai mengenai perencanaan pekerjaan dan berusaha bekerja lebih keras dibandingkan pegawai yang lain. Untuk itu perlu peningkatan motivasi kerja hingga aspek yang lemah dengan cara memberikan semangat kerja dengan memberikan contoh oleh pimpinan sehingga pegawai mau untuk melaksanakan tugas walaupun harus sampai di luar jam kerja sehingga dapat meningkatkan keinginan pegawai dalam menghasilkan kinerja yang optimal.

Gambaran disiplin kerja berada pada kategori cukup baik. Meskipun begitu masih terdapat beberapa aspek yang belum memadai seperti menerima sanksi dan memahami ketegasan untuk meningkatkan disiplin. Perlu ditingkatkan hingga aspek yang lemah dengan cara memberikan contoh bagaimana untuk bertanggung jawab atas kesalahan yang dilakukan kepada pegawai dan memberikan arahan yang efektif sehingga pegawai dapat meningkatkan disiplin kerjanya. Gambaran kepuasan kerja berada pada kategori cukup baik. Meskipun begitu masih ada aspek yang belum memadai yaitu puas atas pesangon dan kesempatan untuk rotasi/mutasi kebagian yang lebih nyaman dan menjanjikan. Demikian perlu dingkatkan hingga aspek yang lemah dengan cara memberikan pesangon lebih agar dapat menjamin masa depan pegawai serta memberikan peluang bagi pegawai untuk mau melakukan rotasi kerja. 
Variabel motivasi kerja mempengaruhi kepuasan kerja secara signifikan. Ini menunjukkan bahwa semakin baik Motivasi Kerja akan semakin meningkat kepuasan pegawai. Disiplin kerja mempengaruhi kepuasan kerja secara signifikan. Hal ini menunjukkan bahwa semakin baik Disiplin Kerja pegawai semakin meningkat pula kepuasan pegawai. Variabel motivasi kerja dan disiplin kerja berpengaruh terhadap kepuasan kerja pegawai secara signifikan. Hal ini menunjukkan bahwa semakin kuat motivasi kerja dan semakin disiplin pegawai akan semakin puas pegawai. Dalam upaya peningkatan kepuasan kerja dari sisi kontribusi motivasi kerja, maka sebaiknya instansi melakukan peningkatkan semangat kerja pegawai dalam mendorong kinerja pegawai supaya lebih optimal. Disiplin kerja yang memadai dapat meningkatkan kepuasan kerja pegawai, dengan demikian peningkatan disiplin kerja perlu dilakukan oleh pimpinan.

Penelitian ini hanya mengkaji masalah motivasi kerja dan displin kerja terhadap kepuasan kerja pegawai sehingga memiliki beberapa kekurangan dalam hasil pengujian secara komprehensif, untuk itu perlu adanya kajian yang lebih jauh baik dengan menggunakan sample yang lebih besar maupun variabel lainnya yang berpengaruh terhadap kepuasan kerja pegawai.

\section{REFERENSI}

Avery, R. E., Smillie, L. D., \& Fife-Schaw, C. R. (2015). Employee achievement orientations and personality as predictors of job satisfaction facets. Personality and individual differences, 76, 56-61.

Cantarelli, P., Belardinelli, P., \& Belle, N. (2016). A meta-analysis of job satisfaction correlates in the public administration literature. Review of public personnel administration, 36(2), 115-144.

De Sousa Sabbagha, M., Ledimo, O., \& Martins, N. (2018). Predicting staff retention from employee motivation and job satisfaction. Journal of Psychology in Africa, 28(2), 136-140.

Dyrbye, L. N., Shanafelt, T. D., Johnson, P. O., Johnson, L. A., Satele, D., \& West, C. P. (2019). A cross-sectional study exploring the relationship between burnout, absenteeism, and job performance among American nurses. BMC nursing, 18(1), 1-8.

Hersona, S., \& Sidharta, I. (2017). Influence of leadership function, motivation and work discipline on employees'performance. Jurnal Aplikasi Manajemen, 15(3), 528-537. 
Islami, X., Mulolli, E., \& Mustafa, N. (2018). Using Management by Objectives as a performance appraisal tool for employee satisfaction. Future Business Journal, 4(1), 94-108.

Manik, E., \& Sidharta, I. (2017). The Impact of Motivation, Ability, Role Perception on Employee Performance and Situational Factor as Moderating Variable of Public Agency in Bandung, Indonesia. International Journal of Management Science and Business Administration, 3(4), 65-73.

Nath Gangai, K., \& Agrawal, R. (2015). Job satisfaction and organizational commitment: Is it important for employee performance. International journal of management and business research, 5(4), 269-278.

Raza, M. Y., Akhtar, M. W., Husnain, M., \& Akhtar, M. S. (2015). The impact of intrinsic motivation on employee's job satisfaction. Management and organizational studies, 2(3), 80-88.

Sidharta, I. (2018). Behavior performance: a validity of performance management behavior questionnaire (PBQ) instrument. Jurnal Computech \& Bisnis, 12(2), 171-178.

Smith, P.C., Kendall, L. M., \& Hulin, C.C. (1969). The measurement of satisfaction in work and retirement. Chicago, IL: Rand McNally.

Sofyan, M., Rahman, A., Bima, M. J., \& Nujum, S. (2016). The effect of career development and working discipline towards working satisfaction and employee performance in the Regional Office of Ministry of Religious Affairs in South Sulawesi. International Journal Of Scientific \& Technology Research, 5(03), 51-57.

Trivellas, P., Kakkos, N., Blanas, N., \& Santouridis, I. (2015). The impact of career satisfaction on job performance in accounting firms. The mediating effect of general competencies. Procedia Economics and Finance, 33, 468-476.

Zia-ud-Din, M., Arif, A., \& Shabbir, M. A. (2017). The impact of workplace incivility on employee absenteeism and organization commitment. International Journal of Academic Research in Business and Social Sciences, 7(5), 205-221. 